\title{
NEW OR LITTLE-KNOWN SPECIES OF WEST INDIAN TIPULIDAF (DIPTERA). II.
}

\author{
By Charles P. Alexander \\ Massachusetts State College, Amherst, Massachusetts
}

The first part under this general title was published in the Journal of the Department of Agriculture of Puerto Rico, vol. XX, No. 4, October, 1936, pages 877-882. In the present instalment, $\mathrm{I}$ wish to describe some interesting material collected in Puerto Rico by Messrs. Julio García-Díaz, James G. Needham and Mortimer D. Leonard, and a second rich series taken in Oriente, Cuba, by Messrs. Julián Acuña, Lawrence C. Bruner and L. Scaramuzza. The types of all the novelties are preserved in my collection of crane-flies through the friendly interest of the various collectors.

\section{Dolichopeza (IMegistomastix) acutiloba sp.n.}

General coloration brown, the praescutum with four paler stripes; antennae with inconspicuous pubescence that is much shorter than the scattered, unilaterally arranged verticils; macrotrichia of wing-cells abundant; abdominal: segments bicolorous, the bases of the segments brown, the posterior rings yellow; subterminal segments and hypopygium dark; male hypopygium with apex of each tergal lobe terminating in an acute spine; beak of inner dististyle: relatively slender.

Male.-Length 7-8 mm.; wing 6.5-7.5 mm.

Female.-Length about $9 \mathrm{~mm}$; wing about $9 \mathrm{~mm}$.

Described from alcoholic specimens.

Frontal prolongation of head pale brown; palpi brown, the outer segments slightly paler. Antennae brownish black, the pedicel yellow; flagellar segments broken beyond the third, but when entire the organ must be as long as, or longer than, the entire body; flagellar segments with scattered elongate verticils, unilaterally distributed, together with a very short, inconspicuous pubescence. Head brown, the front and orbits more brightened.

Pronotum brown. Mesonotal praescutum brown, with four paler stripes that are very poorly defined against the ground; scutal lobes a little darker than the median area; scutellum and postnotum brown. Pleura obscure yellow, indistinctly variegated with darker, especially on the anepisternum and ventral sternopleurite. Halteres dusky, the knobs whitened. Legs with the coxae brown; trochanters yellow; remainder of legs brown. Wings brownish gray; stigma oval, darker brown; veins brown. Macrotrichia of cells abundant, involving the outer ends of cells $R, M, C u$ and 1 st $A$, besides the cells beyond the cord. Venation: Petiole of cell $M_{1}$ a little shorter than $m$. The allotype female has cell $M_{1}$ very short-petiolate to nearly sessile. 
Abdominal segments bicolorous, the bases brown, the posterior rings broadly yellow, the amount of the latter decreasing on the outer segments; outermost segments and hypopygium uniformly darkened. Male hypopygium (Fig. 6) with each lateral lobe of the tergite, $9 t$, produced into an acute darkened spine; median area of tergite moderately produced. Outer dististyle, od, shal. lowly and unequally bifid, with a flattened glabrous lobule at base. Inner dististyle, $i d$, with apical beak slender, pale.

Habitat.-Puerto Rico.

Holotype, ô, El Yunque trail, Km. 1.3, June 11, 1935 (GarcíaDíaz); Collector's No. 1200. Allotype, + , Picnic Grounds, Luquillo Mountains, June 7, 1935 (García-Díaz); No. 1082. Paratopotypes, 2 of of, with the type, No. 1158, June 10, 1935; No. 1787, same date; paratype, 1 \%, Luquillo Mountains, No. 46, June 10, 1935 (García-Díaz); No. 1182.

Dolichopeza (Megistomastix) acutiloba is most nearly related to $D$. (M.) obtusiloba sp.n., in the short, inconspicuous pubescence of the male antennae. The two species are most readily told from one another by the structure of the male hypopygium, especially the lateral lobes of the ninth tergite. The paratype female (No. 1182) has the petiole of cell $M_{1}$ unusually long, considerably exceeding $m$, and with a distinct darkened cloud on the anterior cord. It may pertain to a different species.

\section{Dolichopeza (Megistomastix) obtusiloba sp.n.}

Male.-Length about $7.5 \mathrm{~mm}$., wing $8 \mathrm{~mm}$.

Described from alcoholia specimens.

Characters very similar to those of acutiloba sp. n., differing especially in the structure of the male hypopygium. Pubescence of flagellar segments pale, a trifle longer and more erect than in acutiloba but still less than a fifth as long as the conspicuous erect black verticils. Thoracic pattern much as in acutiloba. Wings with unusually abundant macrotrichia, which include nearly the outer two-thirds of cell $R$ and the outer end of cell 2nd $A$, as well as being very abundant in all outer cells. Venation: Union of $R_{1}$ and $R_{2}$ angulated and, in cases, with a spur of $R_{1}+_{2}$ persisting beyond the point of their union. Abdomen bicolorous, as in acutiloba, the pattern persisting to the outer segments; hypopygium pale. Male hypopygium (Fig. 7) with the lateral arms of tergite, $9 t$, relatively long and conspicuous, at ends a little expanded into a head and provided with blackened spinous setae; median area of tergite strongly produced. Outer dististyle, od, deeply bifid, the inner arm very strongly capitate and set with abundant short dark setae; outer arm clavate, clothed with much longer setae. Inner dististyle, $i d$, with the apical beak very stout; lobe at its base darkened.

Habitat.-Puerto Rico.

Folotype, ô, El Yunque trail, Km. 1.3, July 27, 1935 (García- 
Díaz) ; Collector's No. 1477. Paratopotypes, 1 s, Luquillo Mountains, west of swimming pool, November 18, 1935 (Needham \& GarcíaDíaz) ; No. 25; 1 o, Trout's Creek No. 1, Luquillo Mountains, June 9, 1935 (García-Díaz), No. 1122.

\section{Dolichopeza (Megistomastix) vittinervis sp.n.}

Antennae black throughout; mesonotal praescutum dark brown, with three grayish stripes, the broad median vitta vaguely divided by a dusky median line; pleura brownish gray, variegated with obseure yellow on the dorsal sternopleurite, ventral pteropleurite and meral region; knobs of halteres weakly infuscated; wings tinged with dusky; cells $C$ and $S c$ brown, cord and veins $C u$ and 2 a $A$ seamed with brown; abundant, dark-colored macrotrichia in cells $Z_{i}$ to $M_{i}$, inclusive, not reaching the cord of wing and not including cells $C u$ or 1 st $A ; m$ subequai to the petiole of cell $M_{1}$.

Female.--Length about $7.5 \mathrm{~mm}$; wing $\mathrm{s} \mathrm{mm}$.

Frontal prolongation of head dark grayish brown; palpi brownish black. Antennae black, only the pedicel a very little paler; basal flagellar segments of moderate length, with very short, delicate setulae and seattered longer verticils; outer segments shorter. Fead brownish gray.

Mesonotal praescutum with the ground-color dark brown, with three grayish stripes, the median one broad, vaguely divided by a dusky median line; scutum with median area clear gray, the lobes more infuscated; scutellum and mediotergite clearer gray. Pleura chiefly brownish gray, variegated by an obscure yellow on the dorsal sternopleurite, pteropleurite and meral region but not forming a distinct longitudinal stripe; dorsopleural membrane light brown. Halteres pale, the knobs weakly infuseated. Legs with the coxae brownish gray; trochanters yellow; femora obscure brownish yellow, the tips narrowly darker; tibiae and tarsi infuscated. Wings (Fig. 1) with a strong dusky tinge, cells $C$ and So brown; stigma and relatively conspicnous seams on anterior cord, posterior cord, and veins $C u$ and 2 nd $A$ darker brown; veins and maerotrichia dark brown, conspicuous. Macrotrichia abundant in cells $R_{1}$ (stigma), $R_{2}, R_{3}$, $R_{5}, M_{1}$, 2nd $M_{2}, M_{3}$, and $M_{4}$, not attaining the bases of the cells and not crossing basad of cord (position of trichia shown in figure by stippled dots); no trichia in cells $C u$ or 1 st $A$. Venation: $R_{1}+=$ represented only by a tiny spur; $m$ arcuated at near midlength, subequal to the petiole of cell $M_{1} ; M_{3}+_{1}$ short, with $m-c u$ at its fork.

Abdomen badly discolored by eggs within body; tergites chiefly light brown; cerci appearing as strongly compressed blades, their tips obtuse; hypovalvae very reduced.

Habitat.-Cuba (Oriente).

Holotype, ㅇ, Loma del Gato, Sierra del Cobre, altitude 2600-3325 feet, September 25-30, 1935 (Acuña, Bruner and Scaramuzza).

Dolichopeza (Megistomastix) vittinervis is quite distinct from the other species of the subgenus so far made known. It is apparently closer to the Puerto Rican species than it is to $D$. (II.) cubensis (Alexander) of western Cuba. The darkened antennae, pattern of 
praescutum and wings, and the restriction of the very conspicuous wing-trichia provide good characters for the separation of the species.

\section{Limonia (Rhipidia) tetraleuca sp.n.}

General coloration yellow, variegated by brown; antennae brown, with four subterminal segments white; knobs of halteres variegated with white; posterior tarsi with three subterminal segments light yellow; wings creamcolored, the posterior cells darker; a relatively heavy darker brown costal pattern, the areas at origin of $R s$ and fork of $S c$ disconnected; wing-tip and axilla pale; basal abdominal segments whitened, the succeeding tergites with a brown median vitta.

Female.-Length about $7.5 \mathrm{~mm}$; wing $6.7 \mathrm{~mm}$.

Described from the alcoholic type.

Rostrum black, the labial palpi paler; maxillary palpi black throughout. Antennae black, with segments ten to thirteen, inclusive, abruptly white; pedicels of the intermediate flagellar segments a little paler than those of the more basal ones; flagellar segments moderately produced, with conspicuous glabrous apical pedicels that become more elongate and slender on outer segments; terminal segment nearly as long as the preceding two taken together, its distal third narrowed. Head dark brown.

Pronotum dark medially, paler on sides. Mesonotal praescutum with an irregular dark pattern, the median stripe broad and entire on posterior half, interrupted and reduced to a capillary median vitta on anterior half, at cephalie border continuous with a narrowly darkened border; the latter area at its outer end has a sinuous broken stripe extending backward to the suture, roughly paralleling the median vitta, as described; scutum pale medially, the inner margin of each lobe entirely traversed by a dark brown stripe that extends to the chiefly darkened scutellum; mediotergite dark brown, with a conspicuous pale spot at each antero-lateral portion. Pleura chiefly pale, traversed by two longitudinal brown stripes, the more dorsal one much wider, extending from the propleura to beneath the abdomen. Halteres variegated, the base of stem yellow, the distal half black; knob black, extensively variegated with whitish. Legs with the coxae chiefly pale, traversed by the ventral pleural stripe; trochanters pale; remainder of legs dark brown, the posterior tarsi with segments two to four, inclusive, entirely light yellow. Wings with the cephalic half cream-colored, the posterior portion more darkened; anterior border variegated by about six large darker areas, the fourth (origin of $R s$ ) and fifth (fork of $S c$ ) disconnected; a narrow subterminal darkened fascia; wingtip, in cells $R_{2}$ to 2nd $M_{2}$, inclusive, pale; cord and outer end of cell 1 st $M_{2}$ narrowly darkened; axilla, in both anal cells, conspicuously white; veins brown, $C u$ yellow. Venation: $S c_{1}$ ending shortly beyond midlength of $R s$, $S c_{2}$ at its tip; cell 1st $M_{2}$ relatively long, its inner end strongly arcuated, with $m-c u$ at fork of $M$.

Abdomen with the first segment and base of the second pale, the remaining tergites conspicuously darkened medially, narrowly pale on sides; darkened area narrowed behind, the pale borders correspondingly widened; sternites yellow. Ovipositor with the cerci small and weak, darkened, not extending caudad beyond the tips of the hypovalvae. 


\section{Habitat.-Puerto Rico.}

Holotype, 우, El Yunque trail, Km. 1.3, July 7, 1935 (GarcíaDíaz); Collector's No. 1419-43-35.

The present fly is most nearly allied to Limonia (Rhipidia) subcostalis Alexander (Central America), differing especially in the paitern of the thoracic dorsum, abdomen and antennae. I had earlier (Dept. Sci. \& Agr. Jamaica, Ent. Bull. 4 : 21-22; 1929) reported subcostalis from Jamaica, but it now appears more probable that the latter material represents a still different species. It is unfortunate that the males of several of these forms are still unknown.

\section{Shannonomyia scaramuzzai sp.n.}

General coloration dark brown, the pronotum and lateral pretergites ashygray; legs brownish yellow, the terminal tarsal segments darker; wings almost uniformly tinged with gray, the stigma pale brown; $R_{3}$ oblique, nearly twice $R_{1}+_{2} ; R_{2}$ subeaual to $R_{2}+_{3}$; cell 1 st $M_{2}$ closed; abdomen dark brown; hypopygium obscure brownish yellow.

Male.-Length about 4-4.2 mm.; wing $3.8-4 \mathrm{~mm}$.

Female-Length about $5.5-6 \mathrm{~mm}$; wing $4.5-4.8 \mathrm{~mm}$.

Rostrum and palpi black. Antennae brown to dark brown, the scape more or less pruinose; flagellar segments subglobular to short-oval, the outer ones a trifle longer; verticils about twice the length of the segments. Head dark grayish brown.

Pronotum light ashy-gray, the coloration continued caudad on the lateral pretergites to the wing-root. Mesonotum uniformly dark brown, the praescutum unstriped. Pleura dark brown, sparsely pruinose. Halteres pale to slightly dusky, the knobs slightly more infuscated. Legs with the coxae and trochanters obseure yellow; remainder of legs brownish yellow, the terminal tarsal segments darker. Wings (Fig. 2) almost uniformly tinged, with gray; stigma oval, pale brown, bisected by $R_{2}$; veins pale brown. Macrotrichia of veins very variable, in cases with numerous trichia on veins beyond cord, including a series of about a dozen on $R_{3}$, in other specimens $R_{2}+_{3}+_{4}, R_{3}+_{4}$ and $R_{3}$ without trichia. Venation: $S c_{1}$ ending opposite midlength of $R s, S c_{2}$ at its tip; $R s$ angulated to weak-spurred at origin; $R_{2}$ subequal to $R_{3}+_{4} ; R_{3}$ oblique, nearly twice $R_{1}+_{2}$; cell 1st $M_{2}$ closed, exceeding in length vein $M_{4}$ beyond it; $m$-cu about two-thirds its length beyond fork of $M$.

Abdomen dark brown; hypopygium obscure brownish yellow.

Habitat.-Cuba (Oriente).

Holotype, ㅇ, Loma del Gato, Sierra del Cobre, altitude 2600-3325 feet, September 25-30, 1935 (Acuña, Bruner and Scaramuzza). Allotopotype, ㅇ․ Paratopotypes, 1 î, 1 우; paratypes, several of both sexes, Pico Turquino, Sierra Maestra, altitude 3750 feet, June 12, 1936, at light (Acuña).

I take much pleasure in namiing this fly in honor of Mr. L. Scaramuzza, who collected part of the type series. The fly is amply 
distinct from the other Antillean species so far made known. It differs from brevicula Alexander and mesophragma Alexander, in the venation and in the virtually unmarked wings. In the latter regard it comes closer to triangularis Alexander, of Puerto Rico, which has cell $M_{2}$ of the wings open.

\section{Gnophomyia (Gnophomyia) diazi sp.n.}

Size small (wing, ᄋ, $4.7 \mathrm{~mm}$.); general coloration black, including antennae, halteres and legs; wings nearly hyaline, with conspicuous black veins; $R_{2}+_{3}+_{4}$ very strongly areuated, nearly erect; cerci with setae to extreme tips.

Female-Length about $5 \mathrm{~mm}$; wing $4.7 \mathrm{~mm}$.

Described from the alcoholic type.

Head and appendages black; flagellar segments of antennae oval, the verticils subequal in length to the segments.

Thorax and appendages black. Wings (Fig. 3) nearly hyaline; stigma faintly indicated as a cloud beyond $R_{2}$; veins black, conspicuous. Venation: $R_{2}+_{3}+_{4}$ very strongly arcuated, nearly erect; $R_{2}$ subequal to $R_{8}+_{4} ; R_{3}$ close to $R_{1}+_{2}$, slightly upcurved at its tip; cell $R_{3}$ at margin wider than cell $R_{2}$; cell 1st $M_{2}$ narrowed at proximal end; $m$-cu about one-third its length before fork of $M$.

Abdomen black; terminal segments narrowed, but not as markedly so as in arcuata; cerci with the tips truncated, provided with setae to extreme ends.

Habitat.-Puerto Rico.

Holotype, , Luquillo Mountains, Km. 11.8, Lot 46, June 7, 1935, at light (García-Díaz); Collector's No. 1028-38-35.

I take unusual pleasure in dedicating this species in honor of the collector of the rich series of Puerto Rican Tipulidae discussed in this report. The only related species so far described is the larger Gnophomyia arcuata Alexander (British Guiana), which, besides its major size, differs in the more produced cerci and genital segment, and in slight details of venation and trichiation of the veins. The discovery of a species of Gnophomyia in the Greater Antilles is of unusual interest.

\section{Gonomyia (Lipophleps) monacantha sp.n.}

Male.-Length about 4-4.5 mm.; wing 3.2-4 $\mathrm{mm}$.

Female.-Length about 5.5-6 mm.; wing 4-4.5 mm.

Belongs to the cincrea group; closely allied to helophila Alexander, differing chiefly in the structure of the male hypopygium, notably of the outer dististyle.

The fly has been adequately described and figured under the name helophila Alexander (Journ. Dept. Agr. Puerto Rico, 16 : 373, fig. 
$20 ; 1932$ ), with which species it has been long confused in collections. The receipt of rather numerous specimens from Señor García-Díaz indicates that the Puerto Rican fly is distinct from heloptila, which has a vast range on the American mainland, from Texas as far south as Peru. The structure of the male hypopygium of the two flies is shown by the accompanying figures. $G$. (L.) monacantha (Fig. 8) has a single powerful blackened spine on the inner margin of the outer dististyle. G. (L.) helophila (Fig. 9) has two such spines, both provided with microscopic spinulae.

The various figures of the male hypopygium of helophila hitherto provicled (Ent. News, 27 : 345, fig. 3; 1916. Proc. Acad. Nat. Sci. Philadelphia for 1916 , pl. 29 , fig. $60 ; 1916$ ) are inaccurate as regards the nature of the lobe of the outer dististyle.

Habitat.-Puerto Rico.

Holotype, $\hat{\delta}$, Vieques Island, at light, September 25-27, 1931 (Leonard). Paratypes, 10 alcoholic $\delta$ \&, Yúñez River, June 19, 1935, at light (García-Díaz); Nos. 1279, 1316; 1 ㅇ, Yúñez River, June 22, 1935, No. 1367; 1 \&, Río Blaneo, at light, March 6, 1935 (Needluam \& García-Díaz), No. 1784; 1 \%, Lares, March 22, 1935 (Needham \& García-Díaz), No. 722.

\section{Gonomyia (Lipophleps) orthomera sp.n.}

Belongs to the manca group; coloration yellow, the thorax variegated by brown; pleura weakly striped; male hypopygium with the dististyles terminal in position, the onter a long, slender, nearly straight spine, gradually narrower to the acute tip; phallosome a single median structure, eutirely pale, in slide mounts extending caudad to beyond the tip of the longest dististyle.

Male.-Length about $3.8-4 \mathrm{~mm}$; wing $2.8-3 \mathrm{~mm}$.

Female.-Length about $4.5 \mathrm{~mm}$; wing $3.5 \mathrm{~mm}$.

Described from alcoholic specimens.

Rostrum yellow; palpi dark brown. Antennae brownish black tliroughout, the flagellar segments with elongate verticils in both sexes, longer in the male. Head yellow, the eenter of vertex weakly darkened.

Pronotum yellow. Mesonotum yellow, the praescutum ehiefly covered by three confluent brown stripes; median area of scutum yellow, the lobes brown; scutellum yellow; mediotergite yellow on sides, the central portion more darkened. Pleura yellow, with vague and poorly defined brown longitudinal stripes, tho more clorsal oceupying the propleura, anepisternum and ventral meron, beconing obsolete before the root of halteres. Halteres pale brown, the knobs whitened. Legs with the coxae pale brown; troclanters yellow; remainder of legs brown. Wings strongly tinged with brown, the stigma scareely darker; veins pale. Venation: $S c_{1}$ ending a clistance before origin of $R s$ nearly equal to the length of the latter; branehes of $R s$ strongly divergent near onter ends; $m$-cu before fork of $M$. 
Abdominal tergites pale brown; sternites more yellowish; hypopygium yellow. Male hypopygium (Fig. 10) with the dististyles terminal in position; outer style, od, a long, nearly straight, simple spine that narrows to an acute point, the distal third darkened; inner style about one-half the length of the outer, weakly constricted near midlength. Phallosome, $p$, entirely pale, consisting of a long median structure, gradually narrowed outwardly, the apex slightly exceeding the tips of the longest dististyle.

\section{Habitat.-Puerto Rico.}

Holotype, ô, Tanamá River, March 12, 1935, at light (Needham \& García-Díaz), No. 545-21. Allotopotype, ․ . Paratopotypes, 2 우 ; 1 broken ô, May 11, 1935 (García-Díaz), No. 882-21. Paratypes, 1 ô , 1 우 , Río Cidra, March 23, 1935 (Needham \& GarcíaDíaz), No. 819.

Gonomyia (Lipophleps) orthomera is entirely distinct from all previously described Neotropical members of the subgenus. By my key to the Puerto Rican species of Lipophleps (Journ. Dept. Agr. Puerto Rico, 16 : 371; 1932), the species runs to couplet 3 , being very distinct from bifiligera Alexander, the male hypopygium of which has a single, entirely fieshy dististyle.

\section{Toxorhina (Toxorhina) domingensis sp.n.}

Mesonotum light ashy-gray, the praescutum with three brown stripes, the median one darker than the laterals; rostrum about four-fifths the length of wing; wings pale gray, the prearcular area pale yellow; veins pale brown, relatively distinct against the ground-color; male hypopygium with a slender darkened spine on mesal face of basistyle near tip; dististyle with the outer lobe roughly quadrate in outline; aedeagus lyriform, each arm relatively long, sinuous, drawn out into hair-like points.

Male.-Length, excluding rostrum, about $5.5 \mathrm{~mm}$; wing $5.2 \mathrm{~mm}$.; rostrum alone $4.2 \mathrm{~mm}$.

Rostrum about four-fifths as long as wing, pale brown, darker at outer end. Antennae with seape and pedicel dark brown; flagellum broken. Head brownish gray.

Mesonotal praescutum light ashy-gray, with three brown stripes, the median one darker and more elearly delimited; scutal lobes infuscated, the median area light gray; scutellum darkened basally, the posterior border pale; mediotergite brownish gray, paler laterally. Pleura light reddish brown, sparsely pruinose, with indications of darker longitudinal stripes, especially on the ventral sternopleurite. Halteres pale yellow, the knobs, excepting the tips, weakly infumed. Legs with the coxae light brown, paler at tips; trochanters yellow; remainder of legs pale brown, the tips of tibiae and the outer tarsal segments slightly darker. Wings (Fig. 4) with a pale gray tinge, the preareular area pale yellow; veins pale brown, relatively distinct against the ground. Venation: $S c_{1}$ ending opposite origin of $R s ; R_{1}$ very short, extending beyond the origin of $R s$ to a distance about equal to $r-m$; outer end of cell 1 st $M_{2}$ narrowed; $m$ short, less than one-half $r-m ; m$-cu about onethird its length before the fork of $M$. 
Abdomen, including hypopygium, chiefly_dark brown. Male hypopygium (Fig. 11) with the basistyle bearing a slender darkened spine on inner face near tip. Dististyle, $d$, with the outer lobe extensive, roughly quadrate in outline, the margin blackened, the inner or distal angle slightly more produced than the outer or more basal one. Arms of ædeagus $a$, elongate, each strongly sinuous to produce a lyriform appearance, their tips narrowed into hair-like points.

\section{Habitat.-Santo Domingo.}

Holotype, ô, Sánchez, June 13-18, 1915. Paratopotype, Sex?, San Lorenzo, June 24-26, 1915.

In the structure of the male hypopygium, the present fly is closeest to Toxorhina (Toxorhina) mendosa Alexander (southern Brazil), differing in the details of venation and coloration, and in the structure of the hypopygium, especially of the aedeagus. The species that I have now determined as being $T$. ( $T$.) fragitis Loew, with which the present fly was formerly confused in my collection Del. has a very distinct hypopygium, with the basistyle unarmed and the dististyle and aedeagus entirely different in structure.

\section{Toxorhina (Toxorhina) violaceipennis sp.n.}

Mesothorax deep orange; rostrum, legs and abdomen black; head gray; wings nearly hyaline, the membrane with unusually strong violaceous reflexions; veins black; $r-m$ at near midlength of cell 1 st $M_{2}$.

Male.-Length, excluding rostrum, about $8 \mathrm{~mm}$; wing $7 \mathrm{~mm}$.

Female.-Length, excluding rostrum, about 7.5-9 mm.; wing 5.3-7 mm.; rostrum about $3.8-4 \mathrm{~mm}$.

Rostrum black, approximately one-half the length of remainder of body. Antennae black throughout; seape short. Head gray; anterior vertex relatively wide, a little less than three times the diameter of the pedicel.

Pronotum brownish black. Mesonotum deep orange, the praescutum weakly tinged with brown but without evident stripes. Pleura orange. Halteres brownish black. Legs with the fore coxae darkened, the remaining coxae and trochanters pale; remainder of legs black. Wings (Fig. 5) nearly hyaline, the membrane with unusually strong violaceous reflexions; veins black, very conspicuous against the ground. Venation: $S c_{1}$ ending opposite origin of $R s$, $S c_{2}$ a little removed from tip; $r-m$ at near midlength of cell $1 s t M_{2}$, the first and second sections of vein $M_{1}+_{2}$ subequal; cell 1 st $M_{2}$ closed; m-cu variable in position, from about one-fourth its length before the fork of $M$ to this same distance beyond the fork; cell and $A$ relatively wide.

Abdomen, including genital shield and valves of ovipositor, black. Male hypopygium black; mesal face of basistyle near apex with very abundant blackened setulose spines; apex of basistyle produced into a slender horn or spike. Dististyle blackened, produced into a slender apical beak and with a high outer crest, the entire outer margin microscopically roughened or serrulate. Branches of aedeagus short. Ninth tergite profoundly split along the midline and provided with an extensive triangular area that is densely set with very small, blackened setae and points. 
Habitat.-Cuba (Oriente).

Holotype, $\hat{\jmath}$, Loma del Gato, Sierra del Cobre, altitude 2600-3325 feet, September 25-30, 1935 (Acuña, Bruner \& Scaramuzza). Allotype, + , Pico Turquino, Sierra Maestra, altitude 3750 feet, June 12, 1936 (Acuña). Paratypes, 2 우 으, with the allotype.

Toxorhina (Toxorhina) violaceipennis is very different from all other described species in the Neotropical fauna, the orange mesothorax contrasting markedly with the black rostrum, legs, wing-veins and abdomen. 
Explanation of Figures.

(Symbols: Male hypopygium, $-a$, aedeagus ; $b$, basistyle; $d$, dististyle; $i d$, inner dististyle; $m d$, intermediate dististyle; od, outer dististyle; $p$, phallosome).

Figure 1. Dolichopeza (Megistomastix) vittinervis sp.n., venation.

Figure 2. Shannonomyia scaramuzzai sp.n., venation.

Figure 3. Gnophomyia (Gnophomyia) diazi sp.n., venation.

Figure 4. Toxorhina (Toxorhina) domingensis sp.n., .venation.

Figure 5. Toxorhina (Toxorhina) violaceipennis sp.n., venation.

Figure 6. Dolichopeza (Megistomastix) acutiloba sp.n., male hypopygium.

Figure 7.-Dolichopeza (Megistomastix) obtusiloba sp.n., male hypopygium.

Figure 8. Gonomyia (Lipophleps) monacantha sp.n., male hypopygium.

Figure 9. Gonomyia (Lipophleps) helophila Alexander, male hypopygium.

Figure 10. Gonomyia (Lipophleps) orthomera sp.n., male hypopygium.

Figure 11. Toxorhina (Toxorhina) domingensis sp.n., male hyp. opygium. 

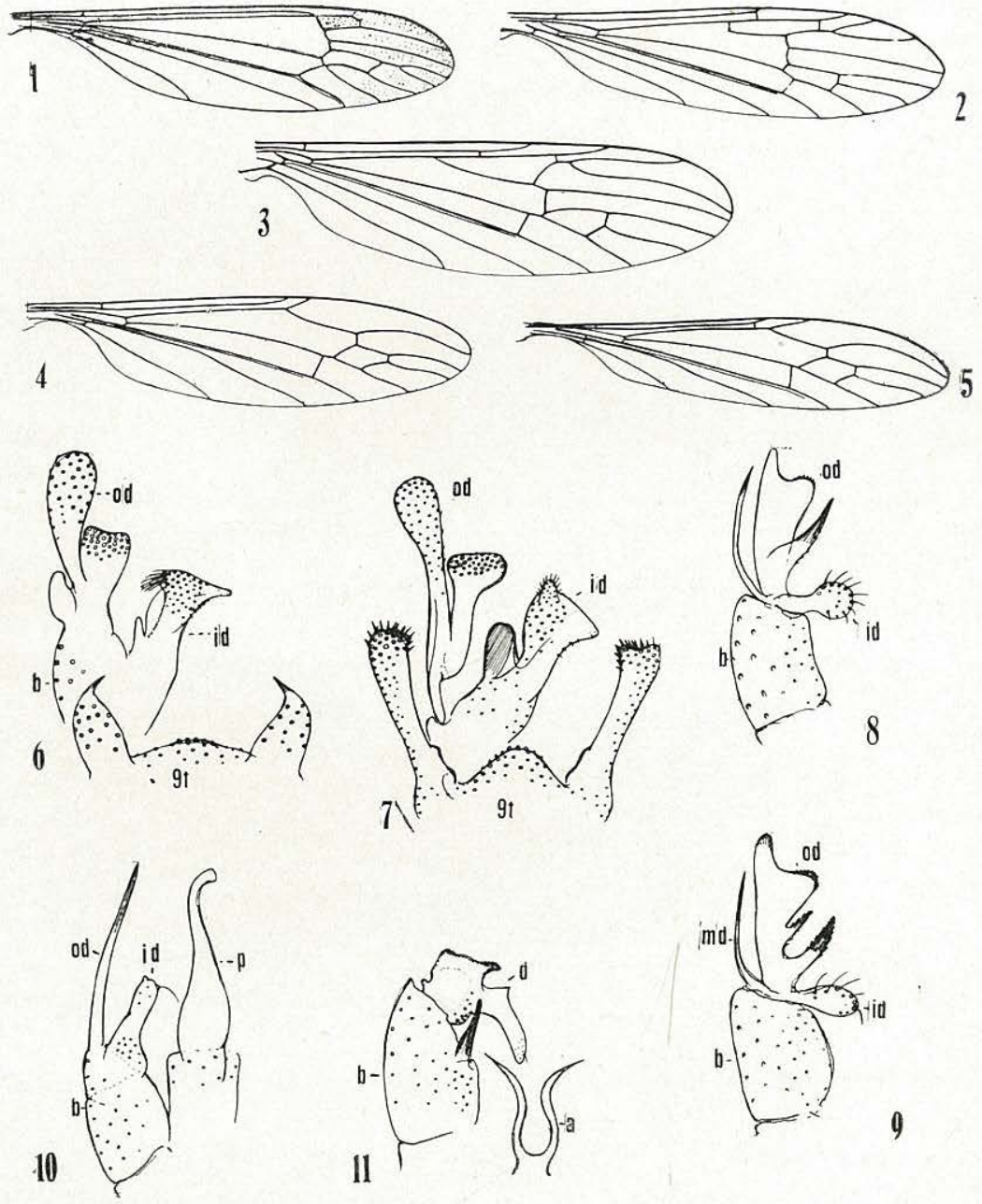